УДК 616.363-003.7-072.1-089.19-06:616.361-089.48

DOI 10.11603/2414-4533.2016.4.7171

() М. Ю. НИЧИТАЙЛО ${ }^{1}$, О. І. ДЗЮБАНОВСЬКИЙ²

Національний інститут хірургії та трансплантології імені О. О. Шалімова НАМН України ${ }^{1}$

ДВН3 “Тернопільський державний медичний університет імені І. Я. Горбачевського”

\title{
Темп декомпресії жовчних шляхів після ендоскопічного транспапі.лярного втручання у хворих з обтураційною жовтяницею на грунті холедохолітіазу (повідомлення 1)
}

\author{
M. YU. NYCHYTAYLO ${ }^{1}$, O. I. DZIUBANOVSKYI ${ }^{2}$ \\ O. Shalimov National Institute of Surgery and Transplantology ${ }^{1}$ \\ I. Horbachevsky Ternopil State Medical University ${ }^{2}$
}

\section{TEMPO OF BILIARY DECOMPRESSION AFTER ENDOSCOPIC TRANSPAPILLARY INTERVENTIONS IN PATIENTS WITH THE OBSTRUCTIVE JAUNDICE DUE TO CHOLEDOCHOLITHIASIS (MESSAGE 1)}

\begin{abstract}
У роботі представлено динаміку біохімічних показників цитолізу та холестазу у 59 хворих на обтураційну жовтяницю, зумовлену холедохолітіазом із різним рівнем білірубіну, на 1-3 та 4-6 добу після транспапілярної ендоскопічної біліарної декомпресії. Темп відповіді жовтяниці на декомпресію визначали за формулою T. Shmizu i K. Yoshida в модифікації Э. И. Гальперина. Встановлено, що у пацієнтів з обтураційною жовтяницею і рівнем гіпербілірубінемії до 100 мкмоль/л і від 100 до 200 мкмоль/л транспапілярна ендоскопічна біліарна декомпресія супроводжується затяжним і помірним темпом відповіді жовтяниці на декомпресію. У хворих із рівнем гіпербілірубінемії >200 мкмоль/л встановлено трансформацію затяжного темпу декомпресії в швидкий темп на 4-6 добу після декомпресії, що може призвести до розвитку синдрому “швидкої декомпресії”.

Dynamics of biochemical indices of cytolysis and cholestasis was presented in examined 59 patients with obstructive jaundice due to choledocholithiasis with different primary levels of hyperbilirubinemia on the 1-3 and 4-6 days after endoscopic transpapillary interventions. Tempo of biliary decompression was calculated using T. Shmizu and K. Yoshida formula in modification of E. I. Halperin. It was found that in patients with obstructive jaundice and bilirubinemia levels less than 100, and 100-200 mcmol/l biliary decompression had protracted and moderate tempo after endoscopic transpapillary interventions. At the same time in patients with bilirubinemia $>200 \mathrm{mcmol} / \mathrm{l}$ tempo of biliary system reaction to decompression changed it character from protracted to fast tempo, that could be the reason of "fast decompression" syndrome.
\end{abstract}

Постановка проблеми і аналіз останніх досліджень та публікацій. Діагностика і лікування жовчнокам'яної хвороби та ії ускладнень залишаються актуальною проблемою сучасної абдомінальної хірургії [1]. Хірургічна тактика при холедохолітіазі, ускладненому обтураційною жовтяницею, сьогодні передбачає дво- та одноетапні міні-інвазивні втручання [2]. Двоетапне лікування включає виконання ендоскопічної ретроградної холангіопанкреатографії (ЕРХПГ) з подальшою ендоскопічною папілосфінктеротомією (ЕПСТ) та літоекстракцією [3]. Одноетапне втручання - це одномоментне виконання лапароскопічної холецистектомії (ЛХЕ) та хірургічної експлорації загальної жовчної протоки [4]. Доведено, що міні-інвазивні методи дренування жовчних проток у хворих на ускладнений холедохолітіаз мають переваги над традиційними відкритими операціями [5].
Незважаючи на значні досягнення та прогрес у хірургічному лікуванні калькульозного холециститу та його ускладнень, невирішеним залишається питання щодо тривалості декомпресії жовчних проток та оптимальних строків радикальної операції [5]. Одні автори стверджують, що нормалізація показників функціонального стану печінки настає через 7-14 днів після біліарної декомпресії [6, 7], і такий термін є оптимальним для виконання другого етапу - лапароскопічної холецистектомії. За даними інших авторів, погіршення стану хворих у післядекомпресійному періоді після ліквідації обтураційної жовтяниці є закономірним явищем $[8,9]$. Нормалізація біохімічних показників крові не завжди збігається за термінами з нормалізацією печінковоклітинної функції, а тому тривалість дренування жовчних проток повинна складати до 4-6 тижнів [8]. Швидка ж ліквідація жовтяниці мо- 
же призвести до погіршення функціонального стану хворого на 4-6 добу після декомпресійного періоду, що пов’язано з “синдромом швидкої декомпресії’ [10].

Мета роботи: визначити темп декомпресї жовчних проток та оцінку показників синдромів цитолізу та холестазу після ендоскопічного транспапілярного міні-інвазивного втручання в пацієнтів із холедохолітіазом, ускладненим обтураційною жовтяницею.

Матеріали і методи. У проведене дослідження включено результати обстеження 140 пацієнтів, у яких було діагностовано обтураційну жовтяницю та яким були проведені одно- та двоетапні декомпресійні операційні втручання при холедохолітіазі.

Як перший етап 59 пацієнтам виконано транспапілярні ендоскопічні декомпресійні втручання, у 55 - одноетапні відкриті операції типу холецистектомія 3 холедоходуоденоанастомозом і в 26 - одноетапні лапароскопічні декомпресійні втручання на жовчних протоках та лапароскопічну холецистектомію. Пацієнтів було поділено на групи відносно рівня гіпербілірубінемії: легкий ступінь - до 100 мкмоль/л, середній ступінь - 100-200 мкмоль/л, тяжкий ступінь - більше 200 мкмоль/л. Усі пацієнти були розподілені у три вікові категорії: 20-59 років (62 пацієнти, що складає 44,3 \% досліджуваної вибірки); 60-74 роки (65 пацієнтів, або 46,4 \% вибірки); 75-89 років (13 хворих, або 9,3 \%).

Було досліджено біохімічні показники холестазу: білірубінемія за методом Ендрасіка-Грофа, активність лужної фосфати (ЛФ); показники цитолітичного синдрому - активність аспартатамінотрансферази (АсАТ) і аланінамінотрансферази (АлАТ) до проведення операційного втручання, а також на 1-3 та 4-6 доби після проведення декомпресії жовчних проток.

Для з’ясування темпу відтоку жовчі було використано модифіковану проф. Э. И. Гальпериным та співавт. [11] формулу відповіді жовтяниці на декомпресії жовчних проток, запропоновану T. Shimizu i K. Yohsida. Графік зниження білірубіну тут відповідає не лінійній функції, а функції натурального логарифму. Темп відповіді жовтяниці на декомпресію оцінювали як: > $5 \leq 10$ - затяжний темп, > $10 \leq 15$ - помірний, $>15 \leq 20-$ швидкий темп.

Статистичну обробку отриманих результатів виконано у відділі інформаційних технологій ТДМУ з використанням програмного пакета Statsoft STATISTICA. Багатофакторний аналіз проведено за допомогою методу лінійної регресії та квартильного методу. Розраховували середнє значення (M) і стандартну похибку середнього (m). Залежно від нормальності розподілу вибірки аналіз відмінностей між двома групами здійснювали за допомогою t-тесту або U-критерію Манна-Уїтні. Відмінності вважали статистично значимими при $\mathrm{P}<0,05$.

Результати досліджень та їх обговорення. Характер операційних втручань у хворих із різним ступенем жовтяниці подано в таблиці 1.

Як видно із таблиці 1, із 85 хворих із легким ступенем жовтяниці (до 100 мкмоль/л) у 63 (74,1\%) були виконані одноетапні радикальні хірургічні втручання. Із них у 41 (48,2 \%) - холецистектомія з холедоходуоденоанастомозом і у 22 (25,9 \%) - лапароскопічна холецистектомія з лапароскопічною холедохолітотомією із літоекстракцією.

У 44 пацієнтів із жовтяницею середнього ступеня тяжкості та у 11 - з жовтяницею тяжкого ступеня переважали двоетапні операційні втручання (28 (63,6 \%) та 9 (81,8 \%) пацієнтів відповідно): транспапілярна ендоскопічна біліарна декомпресія із наступним етапом виконання лапароскопічної холецистектомії.

Якщо провести аналіз розподілу характеру операційних втручань відносно віку (табл. 2), то привертає увагу переважання одноетапних ради-

Таблиця 1. Розподіл характеру операційних втручань за рівнем гіпербілірубінемії

\begin{tabular}{||l|c|c|c|c||}
\hline \multirow{2}{*}{ Показники тяжкості жовтяниці } & \multicolumn{4}{|c||}{ Характер операційних втручань } \\
\cline { 2 - 5 } & ТРПЛ & ХДА & ЛХЕ+ЛХЛ & Всього \\
\hline Легкий ступінь (до 100 мкмоль/л) & 22 & 41 & 22 & 4 \\
\hline Середній ступінь (100-200 мкмоль/л) & 28 & 12 & - & 11 \\
\hline Тяжкий ступінь (більше 200 мкмоль/л) & 9 & 2 & 26 & 140 \\
\hline Всього & 59 & 55 & 44 \\
\hline \hline
\end{tabular}

Примітка. Тут та в інших таблицях:

ТРПЛ - транспапілярна ендоскопічна біліарна декомпресія із наступним етапом виконання лапароскопічної холецистектомії; ХДА - холедоходуоденоанастомоз; ЛХЕ - лапароскопічна холецистектомія; ЛХЛ - лапароскопічна холедохолітотомія із літоекстракцією. 
Таблиця 2. Характер операційних втручань і вік пацієнтів

\begin{tabular}{||l|c|c|c|c||}
\hline \multirow{2}{*}{$\begin{array}{c}\text { Характер операційного } \\
\text { втручання }\end{array}$} & 20-59 років & $60-74$ роки & $75-89$ років & Всього \\
\cline { 2 - 5 } & 3 & 45 & 11 & 59 \\
\hline ТРПЛ & 41 & 12 & 2 & 55 \\
\hline ХДА & 18 & 8 & - & 26 \\
\hline ЛХЕ+ЛХЛ & 62 & 65 & 13 & 140 \\
\hline Всього & & 65 & \multicolumn{5}{|c||}{} \\
\hline
\end{tabular}

кальних операційних втручань серед пацієнтів віком 20-59 років порівняно з паліативними втручаннями. Співвідношення складає 9:1. У віковій групі 60 років і старші спостерігається зворотна тенденція: співвідношення паліативних операцій до одноетапних радикальних складає 7:1.

Проведено аналіз динаміки біохімічних показників сироватки крові після ендоскопічної транспапілярної декомпресії жовчних проток у 59 хворих з різним рівнем гіпербілірубінемії і в різні післядекомпресійні строки (табл. 3-5).

Встановлено достовірне зниження рівня загального і прямого білірубіну крові відносно доопераційних показників. У пацієнтів із рівнем гіпербілірубінемії до 100 мкмоль/л зниження загального і прямого білірубіну на 1-3 доби після операції, відповідно, склало на 52,2 і 28,2 \%, а на 4-6 добу - на 62,9 і 65,0 \% відповідно.

Темп відповіді жовтяниці при проведенні транспапілярної біліарної декомпресії на 1-3 добу після операції був помірним, Beta=14,3. Тоді як на 4-6 добу темп відповіді відповідав затяжномy (Beta=9,62). Показники лужної фосфатази були достовірно знижені на 1-3 і 4-6 доби, відповідно, на 13,8 і 26,1 \% порівняно з доопераційними показниками.

У групі хворих із середнім ступенем тяжкості жовтяниці (гіпербілірубінемія від 100 до
200 мкмоль/л) динаміку зниження рівня загального і прямого білірубіну наведено в таблиці 4.

На 1-3 добу після транспапілярної біліарної декомпресії рівень загального і прямого білірубіну достовірно знизився на 58,9 і 49,9 \% відповідно. Вже на 4-6 добу після операції дані показники знизилися, відповідно, на 90,1 і 87,2 \% (p<0,01). Спостерігали зниження рівня лужної фосфатази на 1-3 доби на 30,0 \% і на 4-6 добу на - 31,7 \% після декомпресії порівняно з доопераційними показниками.

Темп відповіді жовтяниці на транспапілярну декомпресію у пацієнтів на 1-3 доби становив Веta=19,8, що відповідає швидкому темпу, а на 4-6 добу після декомпресії відмічено трансформацію швидкого темпу в помірний (Beta=11,14).

У пацієнтів з тяжким ступенем жовтяниці, рівень гіпербілірубінемії більше 200 мкмоль/л (табл. 5), спостерігали зниження рівня загального і прямого білірубіну на 1-3 доби після декомпреciї на 48,7 і 54,5 \% відповідно, а на 4-6 добу - на 90,7 і 91,3 \% відповідно порівняно з вихідним рівнем білірубіну.

У вказаної групи показник лужної фосфатази знизився на 21,4 і 33,3 \% в 1-3 і 4-6 добу після декомпресії відповідно. Темп відповіді жовтяниці на декомпресію в 1-3 доби після операції був затяжним (Beta=9,66), тоді як на 4-6 добу після де-

Таблиця 3. Динаміка холестатичних показників сироватки крові в різні терміни декомпресії жовчних проток у хворих із вихідним рівнем гіпербілірубінемії до 100 мкмольл, яким проведено транспапілярну біліарну декомпресію

\begin{tabular}{|c|c|c|c|c|c|}
\hline \multicolumn{2}{|r|}{ Показник } & $\mathrm{M} \pm \mathrm{m}$ & $\begin{array}{l}\text { Стандартне } \\
\text { відхилення }\end{array}$ & $\begin{array}{c}\text { Критерій } \\
\text { достовірності (р) }\end{array}$ & Beta \\
\hline \multirow{3}{*}{$\begin{array}{l}\text { Загальний } \\
\text { білірубін, } \\
\text { мкмоль/л }\end{array}$} & До операції (вихідні дані) & $86,3 \pm 8,64$ & 34,7 & - & - \\
\hline & 1-3 доби після операції & $41,22 \pm 4,89$ & 18,98 & $<0,01$ & 14,3 \\
\hline & 4-6 доба після операції & $32,05 \pm 1,1$ & 4,3 & $<0,01$ & 9,62 \\
\hline \multirow{3}{*}{$\begin{array}{l}\text { Прямий } \\
\text { білірубін, } \\
\text { мкмоль/л }\end{array}$} & До операції (вихідні дані) & $52,4 \pm 6,23$ & 23,69 & - & - \\
\hline & 1-3 доби після операції & $37,6 \pm 4,63$ & 17,96 & $<0,01$ & - \\
\hline & 4-6 доба після операції & $18,31,32$ & 5,12 & $<0,01$ & - \\
\hline \multirow{3}{*}{$\begin{array}{l}\text { Лужна } \\
\text { фосфатаза, } \\
\text { ОД/л }\end{array}$} & До операції (вихідні дані) & $321,1 \pm 9,9$ & 23,67 & - & - \\
\hline & 1-3 доби після операції & $276,7 \pm 10,2$ & 32,45 & $<0,01$ & - \\
\hline & 4-6 доба після операції & $237,3 \pm 8,8$ & 15,7 & $<0,01$ & - \\
\hline
\end{tabular}

Примітка. Тут та в інших таблицях критерій достовірності р обчислювався відносно даних до операції. 
Таблиця 4. Динаміка холестатичних показників сироватки крові в різні терміни декомпресії жовчних проток у хворих з різним вихідним рівнем гіпербілірубінемії 100-200 мкмоль/л, яким проведено транспапілярну біліарну декомпресію

\begin{tabular}{|c|c|c|c|c|c|}
\hline \multicolumn{2}{|r|}{ Показник } & $\mathrm{M} \pm \mathrm{m}$ & $\begin{array}{l}\text { Стандартне } \\
\text { відхилення }\end{array}$ & $\begin{array}{c}\text { Критерій } \\
\text { достовірності (р) }\end{array}$ & Beta \\
\hline \multirow{3}{*}{$\begin{array}{l}\text { Загальний } \\
\text { білірубін, } \\
\text { мкмоль/л }\end{array}$} & До операції (вихідні дані) & $183,6 \pm 16,19$ & 69,85 & - & - \\
\hline & 1-3 доби після операції & $75,4 \pm 8,32$ & 35,84 & $<0,01$ & 19,88 \\
\hline & 4-6 доба після операції & $18,09 \pm 0,92$ & 3,91 & $<0,01$ & 11,14 \\
\hline \multirow{3}{*}{$\begin{array}{l}\text { Прямий } \\
\text { білірубін, } \\
\text { мкмоль/л }\end{array}$} & До операції (вихідні дані) & $134,19 \pm 15,04$ & 64,5 & - & - \\
\hline & 1-3 доби після операції & $67,28 \pm 8,66$ & 34,12 & $<0,01$ & - \\
\hline & 4-6 доба після операції & $17,17 \pm 1,2$ & 5,09 & $<0,01$ & - \\
\hline \multirow{3}{*}{$\begin{array}{l}\text { Лужна } \\
\text { фосфатаза, } \\
\text { ОД/л }\end{array}$} & До операції (вихідні дані) & $346,4 \pm 12,2$ & 36,67 & - & - \\
\hline & 1-3 доби після операції & $242,5 \pm 9,4$ & 31,4 & $<0,01$ & - \\
\hline & 4-6 доба після операції & $236,6 \pm 10,3$ & 15,7 & $<0,01$ & - \\
\hline
\end{tabular}

Таблиця 5. Динаміка холестатичних показників сироватки крові в різні терміни декомпресії жовчних проток у хворих із різним вихідним рівнем гіпербілірубінемії >200 мкмольл, яким проведено транспапілярну біліарну декомпресію

\begin{tabular}{|c|c|c|c|c|c|}
\hline \multicolumn{2}{|r|}{ Показник } & $\mathrm{M} \pm \mathrm{m}$ & $\begin{array}{l}\text { Стандартне } \\
\text { відхилення }\end{array}$ & $\begin{array}{c}\text { Критерій } \\
\text { достовірності (р) }\end{array}$ & Beta \\
\hline \multirow{3}{*}{$\begin{array}{l}\text { Загальний } \\
\text { білірубін, } \\
\text { мкмоль/л }\end{array}$} & До операції (вихідні дані) & $264,61 \pm 19,74$ & 49,07 & - & - \\
\hline & 1-3 доби після операції & $135,8 \pm 14,1$ & 29,8 & $<0,01$ & 9,66 \\
\hline & 4-6 доба після операції & $24,5 \pm 2,1$ & 4,5 & $<0,01$ & 20,66 \\
\hline \multirow{3}{*}{$\begin{array}{l}\text { Прямий } \\
\text { білірубін, } \\
\text { мкмоль/л }\end{array}$} & До операції (вихідні дані) & $192,08 \pm 16,19$ & 36,13 & - & - \\
\hline & 1-3 доби після операції & $87,4 \pm 8,65$ & 21,3 & $<0,01$ & - \\
\hline & 4-6 доба після операції & $16,7 \pm 1,37$ & 3,13 & $<0,01$ & - \\
\hline \multirow{3}{*}{$\begin{array}{l}\text { Лужна } \\
\text { фосфатаза, } \\
\text { ОД/л }\end{array}$} & До операції (вихідні дані) & $362,8 \pm 11,7$ & 35,5 & - & - \\
\hline & 1-3 доби після операції & $284,6 \pm 10,5$ & 18,7 & $<0,01$ & - \\
\hline & 4-6 доба після операції & $241,9 \pm 10,9$ & 23,1 & $<0,01$ & - \\
\hline
\end{tabular}

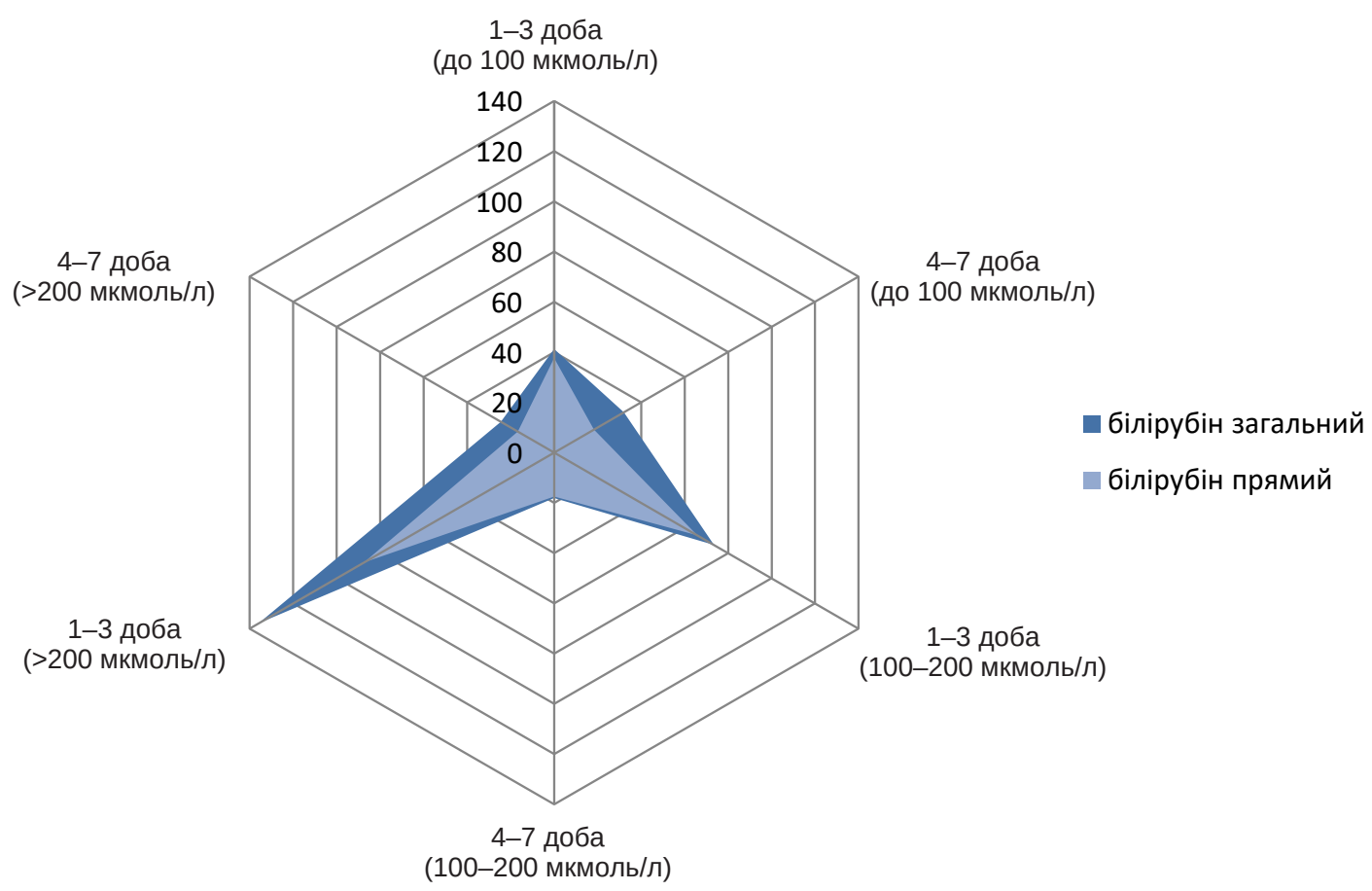

Рис. 1. Динаміка рівня загального та прямого білірубіну (мкмоль/л) в різні терміни декомпресії проток із різним вихідним рівнем білірубінемії у хворих, яким проведено транспапілярну біліарну декомпресію. 
компресії темп відповіді жовтяниці трансформувався в швидкий (Beta=20,66).

Проведено аналіз динаміки показників цитолізу після ендоскопічної транспапілярної декомпресії жовчних проток із різним рівнем гіпербілірубінемії і в різні післядекомпресійні строки (табл. 6-8).

У групі пацієнтів з гіпербілірубінемією до 100 мкмоль/л спостерігали зниження показника АлАТ на 1-3 доби після проведення транспапілярної біліарної декомпресії на 25,1 \%, а на 4-6 добу - на 48,7 \% порівняно з доопераційними показниками. Показники АсАТ у цій групі знижувалися на 1-3 доби після операції на 54,9 \%, і на 4-6 добу - на $49,5 \%$.
У таблиці 7 наведено динаміку показників цитолізу у групі пацієнтів із вихідним рівнем гіпербілірубінемії 100-200 мкмоль/л.

Так, ми спостерігаємо зниження показників АлАТ та АсAТ у 1-3 доби на 42,2 та 36,7 \%, а на 4-6 доби - на 54,6 та 55,1 \% відповідно порівняно з вихідними даними до проведення транспапілярної біліарної декомпресії.

У пацієнтів із холедохолітіазом, ускладненим обтураційною жовтяницею, з вихідними показниками гіпербілірубінемії > 200 мкмоль/л (табл. 8) показники цитолізу змінювалися так: зниження показника АлАТ на 1-3 доби після проведення транспапілярної біліарної декомпресії спостерігалося на

Таблиця 6. Динаміка цитолітичних показників сироватки крові в різні терміни декомпресії жовчних проток у хворих із вихідним рівнем гіпербілірубінемії до 100 мкмольл, яким проведено транспапілярну біліарну декомпресію

\begin{tabular}{||c|c|c|c|c|c|c||}
\hline \multirow{2}{*}{ Показник } & \multicolumn{3}{|c|}{ АлАТ, ОД/л } & \multicolumn{3}{c||}{ АсАТ, Од/л } \\
\cline { 2 - 7 } & $\begin{array}{c}\text { До операції } \\
\text { (вихідні дані) }\end{array}$ & $\begin{array}{c}1-3 \text { доби } \\
\text { після } \\
\text { операції }\end{array}$ & $\begin{array}{c}4-6 \text { доба } \\
\text { після } \\
\text { операції }\end{array}$ & $\begin{array}{c}\text { До операції } \\
\text { (вихідні } \\
\text { дані) }\end{array}$ & $\begin{array}{c}1-3 \text { доби } \\
\text { після } \\
\text { операції }\end{array}$ & $\begin{array}{c}4-6 \text { доба } \\
\text { після } \\
\text { операції }\end{array}$ \\
\hline $\mathrm{M} \pm \mathrm{m}$ & $52,14 \pm 1,92$ & $39,04 \pm 4,92$ & $26,72 \pm 1.28$ & $47,01 \pm 0,78$ & $21,19 \pm 2,58$ & $23,74 \pm 0,89$ \\
\hline $\begin{array}{l}\text { Стандартне } \\
\text { відхилення }\end{array}$ & 12,1 & 16,7 & 18,1 & 21,4 & 4,5 & 5,6 \\
\hline $\begin{array}{l}\text { Критерій } \\
\text { достовірності (р) }\end{array}$ & - & $<0,01$ & $<0,01$ & $<0,01$ & $<0,01$ \\
\hline
\end{tabular}

Таблиця 7. Динаміка цитолітичних показників сироватки крові в різні терміни декомпресії жовчних проток у хворих із вихідним рівнем гіпербілірубінемії 100-200 мкмоль/л, яким проведено транспапілярну біліарну декомпресію

\begin{tabular}{||l|c|c|c|c|c|c||}
\hline \hline \multirow{2}{*}{\multicolumn{1}{|c|}{ Показник }} & \multicolumn{3}{|c|}{ АлАТ, ОД/л } & \multicolumn{3}{|c|}{ АсАТ, Од/л } \\
\cline { 2 - 7 } & $\begin{array}{c}\text { До операції } \\
\text { (вихідні дані) }\end{array}$ & $\begin{array}{c}1-3 \text { доби } \\
\text { після } \\
\text { операції }\end{array}$ & $\begin{array}{c}4-6 \text { доба } \\
\text { після } \\
\text { операції }\end{array}$ & $\begin{array}{c}\text { До операції } \\
\text { (вихідні } \\
\text { дані) }\end{array}$ & $\begin{array}{c}1-3 \text { доби } \\
\text { після } \\
\text { операції }\end{array}$ & $\begin{array}{c}4-6 \text { доба } \\
\text { після } \\
\text { операції }\end{array}$ \\
\hline $\mathrm{M} \pm \mathrm{m}$ & $59,29 \pm 2,72$ & $34,25 \pm 1,27$ & $26,92 \pm 1,41$ & $52,37 \pm 2,21$ & $33,77 \pm 1,82$ & $23,53 \pm 1,37$ \\
\hline $\begin{array}{l}\text { Стандартне } \\
\text { відхилення }\end{array}$ & 6,7 & 14,5 & 7,8 & 21,1 & 14,2 & 9,3 \\
\hline $\begin{array}{l}\text { Критерій } \\
\text { достовірності (р) }\end{array}$ & - & $<0,01$ & $<0,01$ & - & $<0,01$ & $<0,01$ \\
\hline \hline
\end{tabular}

Таблиця 8. Динаміка цитолітичних показників сироватки крові в різні терміни декомпресії жовчних проток у хворих із різними вихідним рівнем гіпербілірубінемії >200 мкмоль/л, яким проведено транспапілярну біліарну декомпресію

\begin{tabular}{||c|c|c|c|c|c|c||}
\hline \multirow{2}{*}{ Показник } & \multicolumn{3}{|c|}{ АлАТ, ОД/л } & \multicolumn{3}{c||}{ АсАТ, Од/л } \\
\cline { 2 - 7 } & $\begin{array}{c}\text { До операції } \\
\text { (вихідні дані) }\end{array}$ & $\begin{array}{c}1-3 \text { доби } \\
\text { після } \\
\text { операції }\end{array}$ & $\begin{array}{c}4-6 \text { доба } \\
\text { після } \\
\text { операції }\end{array}$ & $\begin{array}{c}\text { До операції } \\
\text { (вихідні } \\
\text { дані) }\end{array}$ & $\begin{array}{c}1-3 \text { доби } \\
\text { після } \\
\text { операції }\end{array}$ & $\begin{array}{c}4-6 \text { доба } \\
\text { після } \\
\text { операції }\end{array}$ \\
\hline $\mathrm{M} \pm \mathrm{m}$ & $68,30 \pm 2,06$ & $42,72 \pm 1,29$ & $27,25 \pm 1,32$ & $59,29 \pm 2,35$ & $37,49 \pm 1,42$ & $24,67 \pm 1,33$ \\
\hline $\begin{array}{l}\text { Стандартне } \\
\text { відхилення }\end{array}$ & 21,3 & 12,5 & 10,1 & 12,4 & 11,8 & 6,3 \\
\hline $\begin{array}{l}\text { Критерій } \\
\text { достовірності (р) }\end{array}$ & - & $<0,01$ & $<0,01$ & - & $<0,01$ & $<0,01$ \\
\hline \hline
\end{tabular}


37,5 \%, а на 4-6 добу - на 60,1 \% порівняно $з$ доопераційними показниками. Показники АсАТ у цій групі знижувалися на 1-3 доби після операції на 36,8 \%, і на 4-6 добу - на 58,4 \%.

Загальну динаміку показників цитолізу в різні терміни декомпресії проток із різним вихідним рівнем білірубінемії у хворих, яким проведено

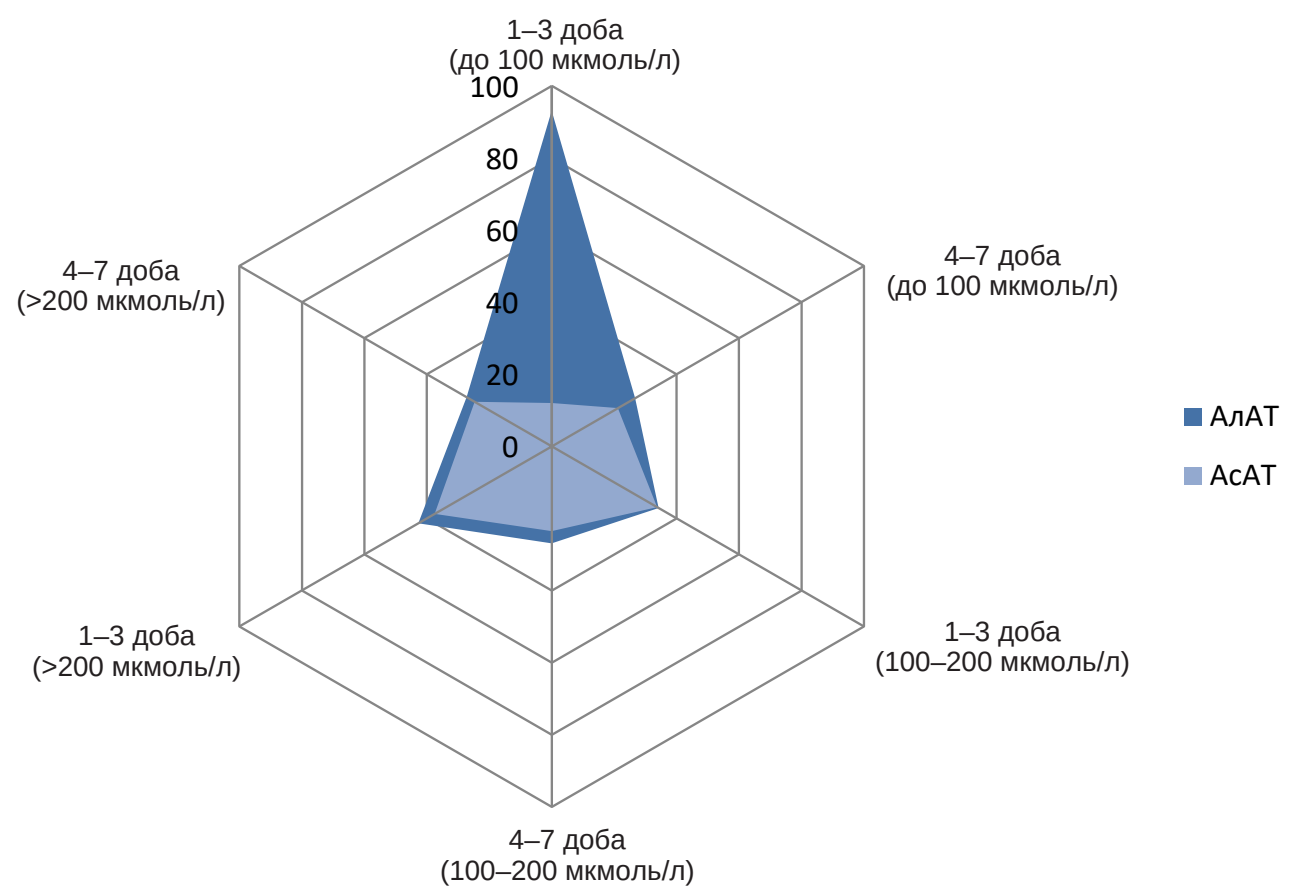

(100-200 мкмоль/л) транспапілярну біліарну декомпресію, представлено на рисунку 2.

Як видно з діаграми, рівні АлАТ перевищували рівні АсАТ при різних рівнях вихідної білірубінемії і були максимальні на 1-3 доби після декомпресійного періоду, що свідчить про можливість виникнення печінковоклітинної недостатності.

Рис. 2. Динаміка середніх показників АлАт, АсАТ (ОД/л) у різні терміни декомпресії проток із різним вихідним рівнем білірубінемії у хворих, яким проведено транспапілярну біліарну декомпресію.

Висновки. Транспапілярна ендоскопічна біліарна декомпресія в пацієнтів з обтураційною жовтяницею і рівнем гіпербілірубінемії до 100 мкмоль/л та у групі від 100 мкмоль/л до 200 мкмоль/л супроводжується затяжним і помірним темпом деком-

\section{СПИСОК ЛІТЕРАТУРИ}

1. Современные аспекты диагностики и хирургического лечения холедохолитиаза (научный обзор) / Я. Г. Колкин, В. В. Хацко, С. В. Межаков [та ін.] // Український журнал хірургії. - 2014. - № 2. - С. 130-135.

2. Захараш М. П. Сучасна діагностично-лікувальна тактика у хворих на механічну жовтяницю, зумовлену холедохолітіазом / М. П. Захараш, Ю. М. Захараш, О. В. Усова // Шпитальна хірургія. - 2010. - № 1. - С. 9-12.

3. Насташенко И. Л. Транспапиллярные вмешательства у больных с неопухолевой билиарной обструкцией / И. Л. Насташенко // Хірургія України. - 2016. - № 2. - С. 56-60.

4. Іванько О. В. Одноетапні хірургічні втручання при гострому холециститі, який ускладнений холедохолітіазом у хворих похилого та старечого вік / О. В. Іванько, Б. В. Свиридюк, І. П. Хоменко // Вісник проблем біології і медицини. 2014. - № 3. - С. 117-120.

5. Дутка Я. Р. Сучасні методи хірургічної корекції механічної жовтяниці у хворих на холелітіаз / Я. Р. Дутка, С. М. Чуклін // Шпитальна хірургія. - 2014. - № 2. - С. 82-87.

6. Современные взгляды на диагностику и хирургичес- пресії, тоді як у хворих з рівнем гіпербілірубінемії >200 мкмоль/л спостерігається трансформація затяжного темпу декомпресії в швидкий на 4-6 добу після декомпресії, що може призвести до розвитку явищ синдрому “швидкої декомпресії”.

кое лечение механической желтухи / Ю. А. Пархисенко, А. И. Жданов, В. Ю. Пархисенко [та ін.] // Український журнал хірургії. - 2013. - № 3 (22). - С. 202-214.

7. Истомин Н. П. Двухэтапная тактика лечения желчекаменной болезни, осложненной холедохолитиазом / Н. П. Истомин, С. А. Султанов, А. А. Архипов // Хирургия. - 2005. № 1. - C. 48-50.

8. Kojama K. Experimental and clinical studies on the effect of biliaje drainage in obstructive janordice / K. Kojama, Y. Takagi, T. Sato // Amer. J. Surg. - 1981. - Vol. 142. - P. 293-299.

9. Мачунин Е. Г. Механическая желтуха неопухолевого генеза. - Мн. : Хорвест, 2000. -160 с.

10. Шевченко Ю. Л. Хирургическая тактика при синдроме механической желтухи // Вестник Национального медико-хирургического центра им. Н. И. Пирогова. - 2009. - Т. 4, № 1. - С. 10-13.

11. Гальперин Э. И. Темп декомпрессии желчных протоков при механической желтухе опухолевой этиологии / Э. И. Гальперин, А. Е. Котовский, О. Н. Момунова // Хирургия. - 2011. - № 8. - С. 33-40. 